\title{
DIE VERHOUDING VAN BELYDENIS EN KERKORDE
}

\author{
DR. C. J. MANS
}

\section{A. BEGRIPSBEPALING:}

Dit is nie moontlik - en seker ook nie nodig - om hier 'n volledige omskrywing van die begrippe „belydenis" en „kerkorde" te gee nie. Ons volstaan daarom met enkele opmerkings wat vir ons doelstelling ter sake is naamlik om die verhouding van belydenis en kerkorde te probeer bepaal.

\section{Belydenis:}

Die woord „belydenis" word hier gebruik in die sin vari "geloofsbelydenis". Die belydenis (of dan ook geloofsbelydenis) is die antwoord van die kerk op die Woord van God. Ons skrywe "Woord" hier met 'n hoofletter (W) omdat die Woord waarop die belydenis van die kerk antwoord is, in die eerste en laaste instansie die Here Jesus Christus self is, want $\mathbf{H y}$ is dit van Wie die Bybel getuig en van Wie die kerk op grond van die Bybel getuig dat $\mathrm{Hy}$ die Here is.

Uit hierdie omskrywing van die begrip „belydenis” is drie dinge reeds duidelik:

i. Die belydenis is kerklike spreke.

ii. Dit is egter menslike spreke. Om met Barth ${ }^{1}$ ) te spreek nie "unbeachtliches, sondern hoch beachliches Menschenwort". Die Woord van God staan altyd bo hierdie menslike antwoord van die kerk net soos die hemel altyd bo die aarde is. Ten opsigte van die Bybel, maar dan ook net ten opsigte van die Bybel, is die belydenis altyd relatief.

iii. As menslike antwoord op die Woord van God is die belydenis deur God self "ge-evoceer"'). God roep self om die antwoord op die vraag: Wie sê julle is Ek (Matt. 16:15)? Uit die niks van die sonde roep Hy self die antwoord van die belydenis in aansyn: „U is die Christus, die Seun van die lewende God" (Matt. 16:16).

Die belydenis het egter ook 'n geskiedenis. Daar was bepaalde menslike redes en motiewe vir sy ontstaan. Gewoonlik word die volgende motiewe genoem: die kategeties-liturgiese- en die dogmaties-polemiese motief. Anders gesê: in die belydenis gaan dit om die regte leer en om die regte lofprysing van God.

1) K. Barth, Kirchliche Dogmatik, Erster Band, Erster Hallsband, Zürich 1947, bl. 281/2. (Gesiteer: KD).

2) A. A. van Ruler, Theologisch Werk, Deel II, Nijkerk 1971, bl. 48. 
Die belydenis is verder getuigend van aard. Dit wil voor alle mense getuig van die kerk se geloof in die Drie-enige God en hulle oproep om saam met hom só te bely3).

Die feit dat die belydenis 'n skriftelike gestalte het, behoort ook in die oog gehou te word.

\section{Kerkorde:}

Met „kerkorde" word bedoel die geheel van algemene bepalings van die kerk wat die skep van orde en reg in die lewe en werk van die kerk ten doel het.

Die kerkorde is dus, veral wat die Calvinisme betref ' $n$ spesifiek kerklike onderneming. Dit is egter nie 'n willekeurige onderneming nie. Dit blyk dat die Konvent van Wezel reeds drie grondslae geken het waaruit normatiewe riglyne vir die kerkreg ontleen kon word naamlik die Woord van God, die gebruik en voorbeeld van die apostels en die ononderbroke gewoonte in die kerk. In die Acta van Wezel word dan ook talle tekste gesiteer as bewys vir wat gestel is. Die Woord van God is dus ook vir die kerkorde, net soos vir die belydenis onontbeerlik. Dit'buig voor die Skrif as die Woord en wil van die Heer van die kerk.

Die kerkorde is juridies van aard. Dit wil die lewe en werk van die kerk kerkregtelik orden. Die woordjie ,kerk” in ,kerkregtelik" dui egter reeds daarop dat die reg op grond waarvan hier georden word sui generis is.

\section{B. DIE ROOMSE OPVATTING VAN KERKREG:}

Die hervormde kerkorde (en ook kerkreg), vir soverre dit sy oorsprong in die Hervorming van die sestiende eeu het, is heelduidelik uit verset teen die Rooms-Katolieke Kerk en die Roomse kerklike reg gebore.

Rome het homself toe soos nou beskou as die één, groot, sigbare heilsinstituut vir die hele wêreld met één liturgie, één belydenis, één kerktaal en één sentrale regering waarvan die pous, die opvolger van Petrus en die plaasvervanger van Christus, die hoof is. Die pous is volgens Rome nie net die hoogste leergesag nie maar by hom berus ook die "supreme en volledige jurisdictiemacht".

Vroeër was die canones, dit is die kerklike verordeninge wat deur die algemene konsiles opgestel is, die bron van die kerkreg. Gedurende die middeleeue is die conones egter hoe langer hoe meer as bron van die kerkreg verdring deur die epistolae decretalis van die pous. In Luther se dae was laasgenoemde reeds die vernaamste bron van die kanonieke reg. Die kerk is deur die pous regeer deur middel van die corpus iuris

3) Sien ook A. A. van Ruler, Bijzonder en Algemeen Ambt, Nijkerk 1952, bl. 89 . 
canonici. Op 10 Desember 1520 het Luther die corpus iuris canonici saam met die pouslike bul verbrand. Hierdie daad van Luther was meer as simbolies want daarmee het die hele protestantisme eintlik die Roomse stelsel van kerkreg verwerp.

Die Rooms-Katolieke Kerk huldig die mening dat hy ook prinsipieel mag oor die staat het. Kragtens die Roomse leer van die twee swaarde besit die pous as hoogste kerkvors albei naamlik die geestelike- en die wêreldlike gesag. Hy het dit egter goed gevind om die wêreldlike gesag aan die vorste van die wêreld en die geestelike gesag aan die clerus oor te dra.

\section{DIE LUTHERSE BESKOUING:}

Luther se beskouing oor die kerkreg hang saam met sy leer oor die „zwei Regimenten") - kerk en owerheid. Die kerk, die sfeer waar die Christelike geregtigheid en die geloof werk, moet die evangelie preek. Die kerk is ecclesia docens. Die owerheid moet weer met die wet (ook met beroep op die natuurreg) die wêreld regeer. Die owerheid kan hierdie taak nie met die evangelie verrig nie.

Luther het selfs die ordening van die empiriese kerk aan die owerheid oorgelaat. Tot 'n sekere mate was hy ook daartoe verplig deur die aard van die hervorming in Duitsland waar owerheidspersone dikwels leidinggewende f'gure in die hervormingsbeweging was en politiek mede sy rol gespael het. Die landsowerheid is toegelaat om burgerlike reëlings vir die kerk te tref.

Die Lutherane gee dan ook voorkeur aan die territoriale of konsistoriale kerkregtelike stelsel. „Territoriaal” omdat hier die stelreël cuius regio, cuius religio toepaslik is en waarby $\mathrm{d} e$ landsvors dan die gesag oefen oor die uitwendige georganiseerde verskyningsvorm van die kerk. Die predikantestand weerhou hulle van hierdie regeringswerk omdat hulle geroep is om te preek (Die kerk is immers ecclesia docens!). Dit is ook nie die taak van die lekestand nie want hulle is as ecclesia audiens geroep om gehoorsaam te wees. „Konsistoriaal” kom van die

1) Luther se formulering in sy boek Von Weltlicher Obrigkeit lui soos volg: "Darumb hatt Gott die swey regiment verordnet, das geystliche. wilchs Christen unnd frum leutt macht durch den heyligen geyst unter Christo, unnd das welltiche, wilchs den unchristen und bösen weret, das sie euszerlich müssen frid hallten unnd still seyen on yhren danck ... Darumb musz man dise beyde regiment mit vleysz scheyden und beydes bleyben lassen Eyns das frum macht. das ander das euszerlich frid schaffe und bösen wercken weret, keyns is on das ander gnug yon der Welt. Denn on Christus geystlich regiment kan niemant frum werden fur got durchs welltlich regiment... Wo nu welltlich regiment oder gesetz allein regirt, da masz eytel heuchley seyn ... Wo aber das geystlich regiment alleyn regiert uber land und leutt, da wirtt der boszheyt der saum losz". Aangehaal by W. Niesel, Das Evangelium und die Kirchen, Neukirchener Verlag 1960, bl. 243. 
woord consistorium wat 'n gemengde vergadering van kerklike en politieke persone aandui. Die landsvors oefen sy kerklike gesag uit deur middel van hierdie consistorium ${ }^{5}$ ).

Die Lutherane ken aan die landsvors hierdie mag in kerklike sake toe op grond van die oortuiging dat hierdie gesag 'n kerklike wortel het. Hierdie reg kom die owerheid toe óf as regsopvolger van die biskop of as vernaamste lid van die kerk. Melanchton het reeds aan die owerheid as membrum praecipium van die kerk die cura religionis opgedra.

Ons het by die Lutheranisme dus die verskynsel dat daar 'n noue verband bestaan tussen die regsreëls waarvolgen.; die keiklike sake gereël word en dié wat in die algemeen in die maat. skappy en die staat geld. Hierdie reëlings van die sake van die empiriese kerk berus eintlik by die owerheid. Selfs die kerkreg as vak kon maar gelate in die hande van 'n juridisse dosent gelaat word.

\section{DIE CALVINISTIESE BESKOUING:}

In die lande waar die hervorming onder invloed van Calvyn gestaan het, het sake anders verloop. In hierdie lande het dis hervorming meer van die gewone volk uitgegaan as van die owerheidspersone. Die gevolg was dat in hierdie lande meer konsekwent as by die Lutherane uitgegaan is van die algemene priesterskap van die gelowiges en die coetus fidelium. Hierdie uitgangspunt is gestel teenoor die hiërargies-klerikale stelsel van Rome se kanonieke reg. As gevolg van die geestesdrywery van die sektariërs het die aksent al meer geval op die kerk as kerk van die Woord, dit wil sê „,de Kerk der goddelijke instuten": die van Bijbel sacramenten en geestelijk ambt" $)$. Dit beteken dat die aksent nie lê op die soewereiniteit van die kerkvolk nie, maar op die amp. Elke spoor van hiërargie is egter konsekwent afgewys').

Duidelike afgrensings is ook gemaak teenoor die Lutherse beskouing ten opsigte van die staat se seggingskap oor die kerklike orde. Volgens Artikel XXXVI van die Nederlandse Gelootsbelydenis is daar wel organiese verband tussen kerk en staat maar die selfstandigheid van die kerk in die vrye staat word gehandhaaf. Dit geskied egter só dat die staat sy „wegen zoekt en haar beslissingen treft bij het licht van het Woord Gods, dat

5) Sien hieroor Th. L. Haitjema, Het Kerkrecht in Inleiding tot de Theologische Studie uitgegee onder redaksie van $H$. van Ooyen, Groningen 1946 , bl. $145 \mathrm{v}$.

(i) Vergelyk Th. L. Haitjema. Nederlands Hervormde Kerkrecht, Nijkerk 1951, bl. 12. (Gesiteer: Nedl. Herv. Kerkrecht).

i) In die Discipline Ecclesiastique (1559) van die Franse Kerk lui dit in Art. 1: Premierement que nulle Eiglise ne pourra pretendre principauté ou domination sur lautre; en sedert 1563 in die Acta van die sinodes in suidelike en noordelike Nederland: "Geen ambisdrager zal over een andere ambtsdrager, geen kerk over een andere kerk heersen". 
de Kerk op de kandelaar houdt"s). Hier is nie sprake van die Roomse leer van die twee swaarde nie, maar ook nie van die staat wat oor die orde en die reg van die empiriese kerk beslis soos by Luther nie. In die hervormde kerkorde en kerkreg gaan dit dus slegs om die orde en reg in sacra - dit wil sê om die suiwere kerklike reg; die reg van die kerk om sy eie lewe en werk te bepaal.

Dit word algemeen aanvaar dat Calvyn sy stempel op die hervormde kerkorde-vorming afgedruk het ${ }^{9}$ ). Die Convent van Wezel en die Sinode van Emden het vir beslissings ten opsigte van verskillende sake in verband met die kerkorde heelwat gesag - al was dit geen fundamentele gesag nie - toegeken aan die „,broeders in Geneve”. Wezel en Emden het albei ten opsigte van die kerkorde geput uit die Geneefse voorbeeld van Calvyn se Ordonances Ecclesiastique, maar ook uit die presbiteriaal-sinodale kerkorde van die Frans Kerk, die Discipline Ecclesiastique en die Londonse Kerkorde wat albei duidelike invloed van Calvyn vertoon. Daarbenewens - en dit moet nie uit die oog verloor word nie - het hulle reeds die Nederlandse Geloofsbelydenis gehad wat in Artikel XXVII-XXXII oor die kerk, die ampte en die regering van die kerk handel.

Dit is nie moontlik om die verhouding van belydenis en kerkorde te bepaal sonder om kortliks na Calvyn te luister nie.

Calvyn het hom baie skerp teen die Roomse kerklike reg afgegrens. Hy het dit 'n „onmeetlik barbaarse heerskappy” genoem. Rome heers oor die gelowiges soos „wrede teregstellers”. Hulle bind die gewetens met gebooie wat menslike versinsels is en nie enige betrekking op die Woord van God het nie. Hierdie versinsels, wat Rome beweer uit die sogenaamde kerklike tradisie volg, tas die ryk van Christus aan en verniel die gewetens. En nou is dit so dat vir Rome die hart van die evangelie juis in hierdie menslike versinsels klop. Dit maak die Woord van die Here betekenloos en kragteloos. Dit is 'n nuwe Judaïsme. Dit is afgodediens ${ }^{10}$ ).

Hierop staan ook Artikel XXXII van die Nederlandse Geloofsbelydenis: „En daarom verwerp ons alle menslike vindinge en alle wette wat mense sou wil invoer om God te dien en om daardeur, hos ookal, die gewetens te bind en te dwing".

Calvyn het dit op hierdie uiters skerp wyse teen die Roomse kerklike reg nie omdat hy voorstaander sou wees van 'n matelose libertinisme nie. In sy omskrywing van die wese van die kerk

8) Haitjema, Nedl. Herv. Kerkrecht, bl. 12.

${ }^{\circ)}$ Sien hieroor Haitjema, Nedl. Herv. Kerkrecht, bl. $16 \mathrm{v}$.

10) Calvyn, Inst. IV, $X, 1$. 
maak hy dit duidelik dat die kerk 'n eie orde moet hê. En dit hang nou nie in die eerste plek daarmee saam dat die kerk nou eenmaal in hierdie wêreld leef en daarom noodgedwonge iets van die maatskaplike lewensvorme moet oorneem of dat ook die gelowige mens nie sonder owerheid kan leef nie. Dit gaan vir hom om baie meer. Die kerk het vir Calvyn sy eie orde omdat dit moeder van die gelowiges is en - meer nog - liggaam van Christus is. Christus is die Hoof en die Heer van die kerk. Hy is die unicus legislator ${ }^{11}$ ), die unicus vitae magister ac director $^{12}$ ) van die gelowiges en die hele kerk. Die kerk word van bo, dit wil sê deur sy Heer self, deur sy Gees en sy gawes georden en geregeer. Nie die enkeling of die menigte is vir hierdie orde bepalend nie want regte orde word alleen daar gevind "waar almal in alles die Heer gehoorsaam is" (by Handelinge 15:16), „wanneer almal deur die Gees van Christus gelei word" en die kerk sy liggaam blyk te wees; wanneer die kerk die gemeenskap van die heiliges is waarin elkeen die ander dien met die gawes wat hy ontvang het. Die orde van die kerk is reg as daarin tor uiting kom dat Jesus Christus die enigste Heer en Leermeester is van hulle wat aan Hom behoort (by I Thessalonicense 5:12; Handelinge 8:25; Kolossense 1:25). Net Hy wat hulle vrygemaak het, is hulle Koning en daarom moet hulle net deur die één wet van die vryheid naamlik die heilige Woord van die evangelie regeer word indien hulle die genade wat hulle eenmaal in Christus verkry het, wil behou ${ }^{13}$ ).

Maar hoe moet hierdie orde van die kerk nou daar uitsien? Calvyn verwys ons hiervoor na die Heilige Skrif. Ons moet die voorskrifte van die Heilige Skrif vashou. Hy het self ook hierdie weg gevolg. Ons kan egter baie van hom leer deur te let op hoe hy dit gedoen het. Hy het nie die reëls vir die orde van die kerk direk uit die Bybel afgelees nie. Die Bybel gee nie sulke lynregte voorskrifte vir die orde van die kerk nie.

Calvyn het uit sy kennis van die Bybel die volgende sake wat op die kerkorde betrekking het, beklemtoon:

a) Die geestelike mag van die kerk bestaan in die leer, die regspraak en die maak van wette. Nie een van hierdie sake of selfs al drie saam, is egter doel in sigself nie. Uitdruklik waarsku hy met verwysing na 2 Korinthiërs 10:8 en 13:10 dat die doel waarvoor hierdie geestelike mag van die kerk gegee is nooit uit die oog verloor mag word nie, naamlik dat al die mag van die kerk gerig moet wees op die opbouing van die kerk en nie op sy afbraak nie. Daarom moet almal wat hierdie mag wettiglik ge-

11) Inst. IV, $X, 1$.

12) Inst. IV, $X, 7$.

13) Inst. IV. $X .1$. 
bruik nooit uit die oog verloor nie dat hulle dienaars van Christus en terselfdertyd dienaars van die volk van Christus is nie. En gaan sy betoog voort - die enigste manier om die kerk op te bou is dat die dienaars self hulle bes sal doen om vir Christus sy gesag te bewaar wat slegs dan ongeskonde kan bly wanneer aan Hom gegee word wat Hy van die Vader ontvang het, naamlik dat Hy die enigste Meester van die kerk is. Daarom moet die Woord van God in hierdie saak in volstrekte sin alle gesag hê ${ }^{14}$ ).

Die eerste saak wat Calvyn dus beklemtoon is dat die mag van die kerk (dit is: leer, regspraak en maak van wette) moet dien tot opbouing van die kerk en dit beteken om Christus die enigste Heer en Meester van die kerk te laat wees. Dit kan alleen geskied wanner God se Woord in volstrekte sin alle gesag het. Verder is dit vir Calvyn 'n uitgemaakte saak dat hulle wat wettiglik hierdie mag gebruik dienaars is - dienaars van Christus en dienaars van sy volk.

Die tweede saak wat Calvyn in hierdie verband duidelik raakgesien het, is dat daar vir die opbounig van die gemeente verskillende dienste nodig is. Die sin van hierdie dienste is dat hulle die heerskappy van Christus sal verkondig en proklameer want dit alleen kan die kerk opbou.

In die Ordonances Ecclesiastique lees ons: Daar is vier ordes van take of dienste (quatre ordes d'offices) wat onse Heer ingestel het om sy kerk te regeer (pour le gouvernment de son. Eglise) naamlik herders, leeraars, ouderlinge en diakens. Die belangrike skriftuurplase is vir hom Efesiërs 4:11, 1 Korinthiërs 12:28 en Romeine 12:7 en 8.

Die herders (ook soms deur Calvyn „opsieners" of "dienaars” genoem) het die taak om die Woord van God te preek (pour endoctriner, admonester, exhorter et rependre taut en publiq comme en particulier - soos dit in die Ordonances Ecclesiastique lui) die sa::amente te bedien en die opsig te beoefen saam met die ouderlinge. Die prediking van die Woord is nie net die belangrikste deel van die herder se werk nie, maar dit is ook die belangrikste diens in die kerk. Dit beteken egter nou nie dat die herders nou naar heerskappy oor die kerk kan uitvoer nie want hulle is "eiattlik niks anders as werktuie van die Heilige Gees" nie (by Deut. 18:17).

Die twircede diens is dié van die leeraars of doctores ${ }^{1 i}$ ) wat tot taak lact om voortdurend die kerklike verkondiging te toets aan die Woord van God en te sorg vir die opleiding van die toekomstige herders van die kerk.

14) Vergelyk Inst. IV. VIII. 1 en 8.

15) Sien Inst. IV, I, 1, IV, IV, 1, Ordonances Ecclesiastique en ook by Efesiërs $4: 11$. 
Hierdie eerste twee dienste (herders en leraars) was vir Calvyn van die grootste belang omdat Christus self deur die mond van hierdie ampsdraers met ons wil praat ${ }^{10}$ ). By Efesiërs 4:11 stel hy dit nog sterker: sonder herders en leraars is daar geen leiding van die kerk nie.

Calvyn is egter nie heeltemal duidelik ten opsigte van hierdie diens nie ${ }^{17}$ ). Dit hang seker ook saam met die verskillende situasies waarin hy geskrywe het. In Geneve was daar plek vir die leraar as professor in die teologie in 'n samelewing waarin owerheid, kerk en skool nou verbonde was en waar die aanstelling van leraars geskied het in samewerking met die owerheid. In Frankryk waar die protestante nie kon reken op owerheidsteun nie, ken die Confession de Foy en die Discipline Ecclesiastique (1559) wat met behulp van Calvyn tot stand gekom het, hierdie diens nie $\left.{ }^{18}\right)$.

Die derde diens is die van die ouderlinge (ook opsieners of regeerders) wat saam met die herders die kerklike tug uitoefen ${ }^{19}$ ) dit wil sê die heerskappy van Christus proklameer in die gemeente.

Laastens is daar die diens van die diakens wat die aalmoese beheer en die armes en siekes versorg. Hulle betuig aan ons dat Jesus Christus Hom ook oor die armoede en ellende van ons liggaam ontferm en ons aardse nood wil stili2v).

Calvyn weet dat daar ook van ander ampte of dienste in die Bybel gepraat word, maar hulle was na sy mening tydelik ${ }^{21}$ ). Die wat hy behou het, het hy behou omdat hy uit die Heilige Skrif geleer het dat hierdie vier dienste of funksies voortdurend in die kerk beoefen moet word omdat hulle vir die opbouing van die kerk onontbeerlik is.

Opsommend: Dit staan vir Calvyn vas dat Christus self sy kerk regeer. Hy doen dit egter nie direk deur self sigbaar teenwoordig in sy kerk te wees nie maar "middelik" deur sy Woord en Gees wat deur die ampte gedra word, dit wil sê deur mense.

16) Sien Inst. IV, I, 1.

1i) Oor die onduidelikheid by Calvyn oor die amp van die doctores, sien W. F. Dankbaar, Het Doctorenambt Bij Calvijn, Nederlands Theologisch Tijdschrift, 19de Jaargang, Wageningen 1964, bl. 135-165.

19) Sien ook A. F. N. Lekkerkerker, Oorsprong en Funksie van het Ambt, s-Gravenhage 1971, bl. 135.

19) Sien byvoorbeeld Inst. IV, I, 1 maar ook Romeine 12:8 en 1 Korinthiërs 12:28.

${ }^{20}$ ) Calvyn sluit hiervoor veral aan by die verkiesing van die "sewe" in Handelinge 6 en 1 Timotheüs 5:9.

21) Inst. IV, 111, 8. Calvyn het hierdie onderskeiding tussen „blywende" en "tydelike" ampte van Martin Bucer in Straatsiurg oorgeneem. Calvyn het tydens sy verblyf in Straatsburg (September 1538 tot September 1541) ten opsigte van liturgie en kerkorde baie van Bucer geleer. 
Hierdie mense besit teenoor mekaar (die een amp teenoor die ander) sowel as teenoor die kerkvolk geen ,ampshoogheid" nie. Deur hulle diens word dit duidelik dat die mens nie genoeg kan hê aan homself nie. Sonder die bemiddeling van hierdie dienende mense kan ons nie ,in Christus" wees of selfs dink dat ons volmaak is nie (by Efesiërs 4:12). Daarom noem Calvyn die kerk ook die moeder van alle gelowiges. Om haar te ken is noodsaaklik omdat daar nie ' $n$ ander manier is om die lewe in te gaan as net om in haar skoot ontvang, deur haar in die wêreld gebring te word en deur haar gevoed, bewaar en regeer te word tot aan die einde van ons lewe nie, want ons swakheid laat nie toe dat ons die skool verlaat voordat ons nie ons hele lewe daarin gesluit het $n^{2}{ }^{22}$ ). Dit beteken dat die kerk met sy amptelike verkondiging en regering nie maar net as 'n kinderskool van verbygaande aard beskou kan word nie. Wie dink dat hy hier nie meer kind wil wees nie, wil wyser as Christus wees. In die kerk se amptelike voeding, bewaring en regering gaan dit om niemand anders as van Christus self wat met ons besig is nie.

Dit is nie nodig om hier aan te toon hoe ons in die Nederlandse Geloofsbelydenis die beskouings van Calvyn feitlik tot in die fynste besonderhede terugkry nie ${ }^{23}$ ). Hier wil ons alleen maar stel dat die Nederlandse Geloofsbelydenis met sy belyde oor die Kerk, die Ampte van die Kerk en die Regering van die Kerk (Artikel XXVII-XXXI) die normatiewe gesag was teen die agtergrond waarvan die kerkorde in verskillende ou Nederlandse sinodes (en ook by ons) sy gestalte gekry het. Sonder hierdie artikels van die Nederlandse Geloofsbelydenis sou die kerkorde nooit kon wees wat dit nou is nie. Hier is duidelik bely wat „,kerk” is. Hier is duidelik bely dat hierdie kerk net een ,enigste algemene Opsiener en Hoof" het, naamlik Jesus Christus. Hierdie uitspraak van die Nederlandse Geloofsbelydenis is ten regte die materiële beginsel van die gereformeerde kerkreg genoem ${ }^{2 t}$ ). Baie duidelik word dit ook hier bely dat dit in die kerkorde moet gaan om die instandhouding van die liggaam van die kerk en dat die regeerders daarvoor ,onder mekaar sekere ordinansies mag instel en bevestig maar dat dit nie mag afwyk van wat Christus, ons enigste Meester, vir ons verordineer het nie". Hiermee word in die belydenis onderstreep wat die maatstaf van die kerkorde moet wees naamlik die Woord van God. Alhoewel dit waar is dat die kerkorde nooit, direk uit die Bybel afgelees

22) Vergelyk byvoorbeeld Inst. IV, I, 4.

23) Soos hierbo aangetoon ken die Confession de Foy en die Discipline Ecclesiastique nie die amp van die docteurs. Die Nederlandse Geloofsbelydenis volg die Confession de Foy.

24) Soos byvoorbeeld K. Rieker, Grundsätze reformierte Kirdienverfassung, I.ejpzig 1899. 
kan word nie, is dit van die grootste belang dat dit nooit uit mense willekeur sal ontspring nie. Dit mag nooit ciie ryk van Christus aantas of die gewetens beswaar en vernietig nie.

Uit hierdie feit dat Belydenis en Kerkorde die Heilige Skrif as diepste bron en enigste norm het, moet die verhouding tusse!n Belydenis en Kerkorde ook nader omlyn word.

Wat die belydenis betref, het ons in die inleidende opmerkings gestel dat dit kerklike spreke maar dan as kerklike spreke onmiskenbaar menslike spreke op grond van God se Woord is. Dit is 'n menslike antwoord wat juis daarom relatief ten opsigte van die Woord van God is. In sy belydenis bely die kerk sy geloof in die Die-enige God en sy werk; bely hy wat deur die vreemde geregtigheid van Christus wat deur God se genade deur die geloof ons sondaars, dit wil sê ons ongehoorsame en opstandige rebelle se eiendom geword het, ons gehoorsame kinders van God is. Maar in hierdie selfde belydenis word ook bely dat hulle wat deur God se genadige bemoeienis met sondaars sy kinders gemaak is en wat van die evangelie lewe en deur die liefde gemotifeer word, 'n kerkorde, 'n kerkwet nodig het. Dit is wel dat die Woord nie 'n wet nodig het nie en dat die Gees van God nie 'n behoefte het aan allerlei reglemente nie. Maar dit is ook waar dat die kerk nooit op 'n afgesonderde eiland bestaan nie, maar nog in die wêreld is en dat ook hulle wat aan die kerk behoort nog steeds mense is. Maar dit is verder ook waar dat die geloof nie ordeloos is nie. Die geloof skep juis self orde - die orde van die Hoof (Christus) en die liggaam (die kerk). Omdat die kerk uit begenadigde, in Christus regverdige sondaars bestaan, moet daar kerkorde wees. Buite en sonder wet en orde kan die kerk nie kerk wees nie. Rudolph Sohm en Emil Brunner noem ten onregte die sogenaamde "verrechlichung” van die kerk die groot „Misverständnis der Kirche". Barth ${ }^{25}$ ) het met reg aangetoon dat hierdie beswaar van Sohm en Brunner berus op 'n verkeerde opvatting oor die kerk. Sohm noem die kerk „Geisteskirche”, „Liebeskirche” „Freiwilligkeitskirche”, „Kirche des Glaubens”. Brunner praat weer van 'n ,reine Persongemeinschaft”, „Brudergemeinschaft", „Lebensgemeinschaft”. En - sê Barth - as Brunner nog wel van "Christusgemeinschaft" en "Christusgemeinde" praat, bedoel hy daarmee niks anders as wat Sohm met sy „Liebeskirche" en "Geisteskirche” bedoel nie, naamlik 'n kerk waarvan Jesus Christus slegs 'n predikaat is en die kerk nie gekonstitueer word deur die feit dat Jesus Christus sy enigste Heer en Meester is nie (soos ons byvoorbeeld by Calvyn gesien het nie), maar deur sekere verhoudings waarin die lidmate van die kerk tot Christus en tot mekaar staan.

25) Sien KD IV 2, bl. 769. 
Hier het ons dit reeds te doen met ' $n$ bepaalde verhouding tussen belydenis en kerkorde. Brunner en Sohm verwerp die kerkorde as „Miszverständnis der Kirche" op grond van 'n bepaalde kerkbegrip - 'n kerkbegrip wat anders is as dié van die belydenis. Enige verskuiwing ten opsigte van die belydenis van die kerk moet noodwendig reperkussies in die kerkorde hê of selfs op die beskouing van die kerkorde as geheel. In hierdie verband staan die dogma egter voorop. Dit is die kerkorde wat op die dogma gebou word en nie anders om nie. „Men kan geen enkele aanwijzing geven voor de orde van het kerklijke leven zonder op dogmatisch terrein te komen ${ }^{26}$ ). Indien 'n ander ekklesiologie as die van Artikel XXVII van die Nederlandse Geloofsbelydenis deur Sinode van Emden aanvaar sou wees, sou die weg van die kerkorde-vorming in Nederland en by ons kerk waarskynlik 'n totaal ander koers gevolg het.

Hierdie verhouding omvat egter nog meer. Ons het hierbo (sien begripsbepaling) gestel dat die kerkorde, al is hy (teenoor die getuigende karakter van die belydenis) wesentlik juridies van aard, ook antwoord op die Woord van God is. As antwoord op die Woord van God is die kerkorde dus ook belydend van aard. Ten regte stel Kirche bekenntnismäszigen Charakter". Daarvan is Artikel XXXII van die Nederlandse Geloofsbelydenis 'n duidelike voorbeeld. Die kerkorde is deel van die „ons glo". Ook die kerkorde van die Kurpfalz laat iets hiervan na vore kom. Hier is die belydenis, die Heidelbergse Kategismus weer ingebed in die kerkorde. Belydenis en kerkorde is dus albei antwoord op die vraag: Wie is Jesus van Nasaret? Albei antwoord: Hy is die Here. Hy is die Hoof en die Heer van sy liggaam, die kerk. Hy en net Hy alleen voer hier die heerskappy deur sy Woord en Gees en Hy bedien Hom daarin van die dienste van die ampte en die amptelike akkumulatiewe vergaderings waar nie die mag van die meerderheid voorop staan nie, maar die gesag van God se Woord en Gees.

In hierdie verband is dit ook die moeite werd om na Barth se "christologiese fundering van die kerkorde en kerkreg te luister"`).

Soos Calvyn stel hy dat die orde van die kerk in diens moet staan van die opbouing van die kerk. Hierdie orde volg 'n bepaalde wet. Dit is egter nie 'n „Normenkodex" nie, maar 'n „Kampfaktion” wat hier die gesag voer — 'n „Kampfaktion” teen

26) G. van der Leeuw, Inleiding tot de Theologie, Amsterdam 1935, bl. 203.

2i) W. Niesel, Bekenntnisschriften und Kirchenordnungen der nach Gottes Wort Refornmerten Kirche, Zürich 1938, Vorwort.

28) Barth handel oor die Ordnung der Gemeinde in KD IV/2, bl. 765-824. 
die chaos en die wanorde ${ }^{29}$ ). „Reg” beteken vir Barth dan ook die "regte omgang met die saak" wat aan die gemeente opgedra is ${ }^{30}$ ).

Barth gryp hier terug na 'n onderskeiding wat hy vroeër ten opsigte van die kerk (by hom „Gemeinde”) gewaak het, naamlik die primêre en sekondêre subjek in die begrip $\mathrm{kerk}^{31}$ ). Daarmee bedoel hy dat Jesus Christus die Hoof van die kerk is (primêre subjek) en dat die kerk sy liggaam (sekondêre subjek) is. Jesus Christus is die Hoof van die kerk wat ,seine eigene irdisch geschichtliche Existenzform" is. Die verhouding tussen Hoof en liggaam kan egter nooit omgekeer word nie. Alleen vanuit die Hoof, Christus, kan aangetoon word waarom daar na orde en dus na 'n bepaalde vorm, na wet en reg in die kerk gevra moet word. Dit kan ook slegs vanuit Christus aangetoon word na watter besondere orde, vorm en reg in die kerk gevra moet word ${ }^{32}$ ).

Barth se uitgangspunt is dan 'n christologies-ekklesiologiese begrip van die kerk wat reeds die saak van orde en reg insluit. Die kerk is 'n „brüderschaflichen Christokratie" ${ }^{33}$ ). Dit wil sê: In die kerk as ,die voorlopige daarstelling van die mensheid wat in Christus geheilig is, geld dit aan die eenkant werklik en primêr dat die orde en die gesag van die Een Heilige in Wie almal geheilig is, hier die gesag voer. Aan die anderkant (maar dan as sekondêre subjek) staan die gemeenskap van die heiliges wat teenoor Hom altyd in die verhouding van gehoorsaamheid en onderdanigheid moet $\left.\operatorname{staan}^{34}\right)$. Dit - sê Barth - is die „Ordnungsprinzip”, die „Grundrecht” van die kerk.

Kerkreg is dan „daardie orde wat die kerk vanuit sy grondreg - in gehoorsaamheid aan sy Heer self moet vind, opstel en handhaaf ${ }^{3 \bar{j}}$ ).

Barth ontvou dit vervolgens breedvoerig onder vier gesigspunte. Ons noem net die eerste twee.

a) Vanuit sy „Grundrecht” kan die kerkreg, die kerkorde slegs „Dienstrecht”, „Dienstordnung" wees. Jesus Christus is die Koning en die Heer van die kerk maar $\mathrm{Hy}$ is dit as die dienende, dit wil sê as die Een wat sy Vader en daarmee sy eiendom en

29) KD IV/2, bl. 765v. ,.Im Raum der menschlichen Geschichte ist doch die Erbauung der Gemeinde als Bezeugung der in Jesus Christus geschehen Versöhnung der Welt mit Gott die grosze Kampfaktion gegen dus Chaos und al so gegen die Unordnung".

30) Sien KD IV $/ 2$, bl. 766.

31) Vergelyk KD IV/2, bl. 768.

32) Vergelyk KD IV/2, bl. 768 en 769.

33) $\mathrm{KD} \mathrm{IV} / 2$, bl. 770.

34) Vergelyk KD IV $/ 2$, bl. $768 \mathrm{v}$.

35) KD IV $/ 2$, bl. 781. ". . . Kirchenrecht ser also ... diejenige Ordnung, die die Gemeinde von ihrem Grundrecht her sich selbst . . . im Gehorsam gegen ihrem Herrn selfer zu finden aufzurichten und zu handhaben hat". 
dus alle mense dien"6). Die kerk is deur sy Heer vry gemaak. Hierdie vryheid kan egter slegs vryheid-om-te-dien wees ${ }^{3 i}$ ). Barth pleit dan ook vir die begrip „diens/te” in plaas van ,amp”:").

b) Tweedens stel Barth dat die kerkreg liturgiese reg is. Die kerkreg staan in 'n besondere verhouding tot die gebeurtenis van die Christelike erediens. Die kerk het in die erediens sy „distinkte Mitte" waarin dit geskied wat „das Rechte” is. „Das Rechte” geskied in die kerk as belydenis-, doop-, nagmaals- en gebedsgemeenskap ${ }^{30}$ )).

Wat die verhouding van belydenis en kerkorde betref, hou dit nou die volgende in: Die heerskappy van Christus oor sy kerk word werklikheid wanneer die kerk in die erediens op sy oproep met sy belydenis antwoord. Wat in die lewe en werk van die kerk as reg geld, sal formeel moet ooreenstem met die belyde van die kerk. Die bepalings van die kerkorde moet dus die belydenis volg. Die bepalings kan self nooit liturgiese reëls of artikels van die geloofsbelydenis wees nie. Hulle word egter met die oog op „das liturgische Geschehen das Bekenntnisses” opgestel. Barth karakteriseer hierdie bepalings as juridiese bepalings. Hulle is nie direk nie maar slegs indirek belydend van aard. Kerkreg is mensereg, wat met die oog op die belydenis en so met die oog op dit wat die belydenis bely, opgestel en met die oog op die belydenis ook gehandhaaf moet word. Die gemeente het hierdie „belydende reg" nodig. Word dit as onnodig beskou, dan word daarmee te kenne gegee dat die kerk nie self die vraag hoef te stel na die gehoorsame voltrekking van sy belydenis nie. In die kerkreg onderneem die kerk om sy belydenis in die eerste plek op homself van toepassing te maak en te voltrek. As Christus die Hoof van die kerk is, kan daar geen manier wees waarop hierdie taak omseil word nie. Aldus Barth ${ }^{* 0}$ ).

Samevatend kan ons dus stel:

Dit gaan in die belydenis om die regte leer en die regte lofprysing van God. Hierdie regte leer en regte lofprysing, soos in die belydenis uitgespreek, word deur die kerk self in sy kerkorde op sy lewe en werk toegepas en in juridiese bepalings uitgewerk sodat op hierdie wyse die regte leer en die regte lofprysing van God in die kerk bevorder en die kerk sodoende opgebou kan word. Op hierdie wyse word én in die belydenis én in die kerk. orde bely dat niemand anders as net Jesus Christus die Hoof en Heer van die kerk is nie. Op hierdie wyse dra die kerkorde ook

36) KD IV/2, bl. 782 .

37) Vergelyk KD IV/2, bl. 785 .

33) Sien KD IV/2, bl. 787 .

30) Sien KD IV $/ 2$, bl. $787-800$

40) Vergelyk KD IV/2, bl. 801 . 
'n belydende karakter. Ons het gesien dat Barth slegs van 'n ,indirekte" belydende karakter ten opsigte van die kerkorde wil praat. Dit is begryplik want die kerkorde wil nie in die eerste plek bely nie, maar orden - maar dan orden op grond van die belydenis, dit wil sê terwyl hy soos die kerk bely, wil hy die belydenis toepas op die lewe en werk van die kerk sodat dit in die lewe en werk van die kerk duidelik sal wees dat net Jesus Christus die Heer van die kerk is. Dit beteken dat die kerkorde nooit doel op sigself is nie. Hy kan en mag nooit meer wil wees as 'n hand wat van homself af wegwys na die enigste Heer en Hoof van die kerk nie. Kerkorde en kerkreg kan en mag nooit meer wees as diensorde en diensreg nie. Die lewe en werk van die kerk wat hy dienend orden is die lewe en werk van die kerk wat 'n gemeenskap van dienaars en dienaresse is - mense wat bevry is van die magte van sonde en dood om God en mens te kan dien.

Dit is duidelik dat daar 'n noue verband tussen belydenis en kerkorde bestaan. Die belydenis is „bron", „wortel” en „norm" van die kerkorde. Dit kan egter nie ongekwalifiseerd gesê word nie. Die belydenis is nooit gelyk aan die Woord van God nie. Hy is mensewoord en daarom relatief normerend vir die kerkorde. Agter die belydenis doem die Woord van God self op as die eintlike bron, wortel en norm van die kerkorde. Maar ons het reeds by Calvyn verneem dat die bepalings van die kerkorde nie direk uit die Bybel afgelees kan word nie. Dit beteken dat die kerkorde nog meer relatief ten opsigte van die Woord van God is as die belydenis.

Dit hou nou nie in dat die kerkorde as sodanig maar as iets relatiefs beskou kan word wat 'n mens ligtelik maar kan verbygegaan nie. Van Ruler ${ }^{41}$ ) het dit so gestel: „De vleeswording des Woords impliceert, dat het recht Gods gestalte aanneemt in her recht der mensen, dat het goddelijke recht er volstrekt menselijk gaat uitzien." Juis omdat die gelowige van die vleeswording van die Woord weet en dit bely sal die "relatiwiteit" van die kerkorde met sy menslike bepalings nooit vir hom 'n struikelblok wees nie. Hy sal juis beter as enige ander mens of instansie weet dat die kerkorde noodsaaklik is as - wat Noordmans ${ }^{42}$ ) noem - 'n korreksie op dié grondfout naamlik dat die kerk altyd onder die versoeking verkeer om te meen dat hy min of meer self oor die Gees van God beskik. Gees sonder God is soos dinamiet wat die kerk en die wêreld vernietig. In die koninkryk van God wil God ons regeer deur sy Woord en Gees langs die weg van die ampte en die amptelike vergaderings.

11) A. A. van Ruler, Bijzonder en Algemeen Ambt, Nijkerk 1952, bl. 90.

12) O. Noordmans, Gestalte en Geest, Amsterdam 1955, bl. 272v. 